\title{
Anne Cobby, The Fabliaux as Popular Literature
}

\section{Paola Cifarelli}

\section{(2) OpenEdition}

\section{Journals}

\section{Édition électronique}

URL : https://journals.openedition.org/studifrancesi/4572

DOI : 10.4000/studifrancesi.4572

ISSN : 2427-5856

\section{Éditeur}

Rosenberg \& Sellier

\section{Édition imprimée}

Date de publication : 1 avril 2012

Pagination : 117

ISSN : 0039-2944

\section{Référence électronique}

Paola Cifarelli, «Anne Cobby, The Fabliaux as Popular Literature », Studi Francesi [En ligne], 166 (I | LVI) |

2012, mis en ligne le 30 novembre 2015, consulté le 18 novembre 2021. URL : http://

journals.openedition.org/studifrancesi/4572 ; DOI : https://doi.org/10.4000/studifrancesi.4572

Ce document a été généré automatiquement le 18 novembre 2021.

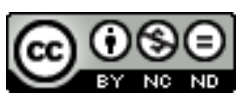

Studi Francesi è distribuita con Licenza Creative Commons Attribuzione - Non commerciale - Non opere derivate 4.0 Internazionale. 


\title{
Anne Cobby, The Fabliaux as Popular Literature
}

\author{
Paola Cifarelli
}

\section{RÉFÉRENCE}

ANNE COBBY, The Fabliaux as Popular Literature, «Reinardus», 22, 2010, pp. 33-49.

1 Il s'agit d'une bibliographie des éditions de fabliaux, ainsi que des traductions, adaptations et nouveaux textes créés à partir des modèles médiévaux; cent cinq titres sont réunis dans ce petit répertoire, qui complète le travail imposant publié par l'A. toujours dans ce domaine (The Old French Fabliaux: An Analytical Bibliography, Woolbridge, Tamesis, 2009); dans la section qui précède la liste des ouvrages, l'A. examine cette vaste production surtout dans l'optique de comprendre ce que les éditions populaires révèlent à propos des intérêts du public non spécialisé concernant ce genre littéraire. 